\title{
CRIMINAL RESPONSIBILITY FOR CONCEALING TRUTH IN FINANCE
}

\author{
Seyyed Ahmad Mir Khalili*
}

Meybod University, Yazd Province, Meybod, Iran, e-mail: dmirkhlili@gmail.com

\author{
Abbas Kalantari \\ Meybod University, Yazd Province, Meybod, Iran, e-mail: abkalantari@gmail.com \\ Fatemeh Rezaei Zarchi \\ Meybod University, Yazd province, Meybod, Iran,e-mail: fatimarezaei@yahoo.com
}

(Received: January 2019; Accepted: April 2019; Published: June 2019)

\begin{abstract}
The disguise of truth as one of the main sources of blameworthy in the Qur'an and the customs has been extremely condemned and has cautioned the concealer. In light of the Quranic documentation and the legitimacy of the disguise of reality, it has been acknowledged and acknowledged that instances of household and outside business sectors that reason doubt of merchants and uncertainty in the monetary space have been a wellspring of perplexity by the gatherings to the agreement. In Iran's law, regardless of the expectation of common risk, including pay and end for hiding reality, no assurance of criminal requirement has been predicted. In this article, alluding to the refrains and portrayals, the standard of wellbeing and the guideline of the supply of products reality in contracts where the purposeful camouflage causes unsalvageable harm, by adjusting the components of wrongdoing, notwithstanding thoughtful risk, for hiding criminal obligation.
\end{abstract}

Keywords: Concealment of Truth, Finance, Subversion, Criminal Responsibility

\section{Introduction}

Contract data and actualities ought to be assembled into two gathering:

A) Data that isn't significant to the gatherings to the agreement to settle on a choice to close an agreement, and quiet in these cases isn't an impact and isn't double dealing or misleading.

B) The data that is important to the gatherings to the agreement in settling on the choice to finish up the agreement, and the camouflage of truth and quietness in

\footnotetext{
${ }^{*}$ Corresponding author: Seyyed Ahmad Mir Khalili.E-mail: dmirkhlili@gmail.com
}

Copyright $(C 2019$ The Author(s). Published by VGWU Press

This is an Open Access article distributed under the terms of the Creative Commons Attribution License - Non Commercial - NoDerivs License (http://creativecommons.org/licenses/by-nc-nd/3.0/) which permits unrestricted use, distribution, and reproduction in any medium, provided the original author and source are credited. 
Mir Khalili, S.A., Kalantari, A., Rezaei Zarchi, F., (2019)

Criminal responsibility for concealing truth in finance

\section{these cases is compel in.}

The fundamental theory of the dealings is in the arrangement of agreements, the trading of data and the statement of realities between the gatherings, so as to both make an evaluation and settle on the exchange or staying away from it. Articulation of realities and the arrangement of complete data at the season of the development of the agreement will prompt the dependability and security of agreements. Actually, on the off chance that one of the gatherings discovers that the data and certainties that have been compelling in its choice isn't known, it can prompt the end or abrogation of the agreement, in this manner undermining the sturdiness and steadiness of the exchange.

The present article looks to find that, notwithstanding considerate risk for an individual disguising an individual, now and again where the spread includes hopeless harm, the criminal law will likewise be founded on the guidelines of law.

\section{Contracts of Truth in Account}

Under the general principle, the gatherings to the agreement are not required to express every one of the certainties identifying with the agreement, gave that the classification of such actualities and quietness in connection to them doesn't delude the other party with regards to the reason sought after by the agreement, as per Article 384 of the Common Code It involves duplicity that a contracting gathering should act misleadingly, and this has an outside appearance, yet at times the provider does not say anything at the season of offer, consequently hiding reality, and the client acknowledges after the buy what he is considering isn't. The inquiry is, can quietness be viewed as a case of disguise of truth and, thus, of deconstruction? In the law, the guideline is that the quiet individual isn't capable, except if it is important to express the quietness of the carriage regarding the matter. In the issue of maligning, the jurisprudent's view can be partitioned into a few classifications:

The main classification: This gathering of law specialists thinks about the deformity of products as evident and blemished. (Ansari, 1411, 3, 128Second class: As per this classification, it is important to educate the purchaser about any imperfections in the products or to ensure that none of the deformities in the merchandise is at risk. (Ansari, 1411, 3, 129

Third class: The divulgence of the imperfection of the products is mustahab and the dealer isn't required to pronounce. (Najafi, 1404, 8, 394

Sheik Ansari uncovers the flaws to the whole of the conclusions of the legal scholars, the gathering's perspective that renders the imperfection mustahab, and passes on the perspective on the other gathering who proclaim the deformity required. (Ansari, 1411, 3, 337) As indicated by The talked about issues can be said that in the hogwash and sleek tune, the declaration of truth is required, yet where 
Mir Khalili, S.A., Kalantari, A., Rezaei Zarchi, F., (2019)

Criminal responsibility for concealing truth in finance

the blame is evident and the client has seen the deformity, the disappointment of the vender isn't fundamental.

A few legal advisors have contended that quiet ought to be deciphered in the light of the particular conditions of each agreement, if in a position of quietness it disguises a fact that beguiles the bartering party, quietness goes up against a positive state for this situation; in such cases, the demonstration ought not be quiet. It is a condition that a quiet individual takes to disguise reality, this state can be viewed as a sort of conduct, and like some other conduct, in the event that it has a mystic component, it is viewed as interweaved (Oseia, 1371, 328)

In each agreement, every one of the gatherings has an obligation to think about its practicality and ought not expect all the data identified with the products to be expressed, yet in situations where that data is compelling in choosing to close the agreement, particularly where the gathering is straightforward and legit He trusts his demonstration is a double dealing, and rights can not go through it. (Katowice, 1395, 5, 330)

As per one of the legal counselors in such manner: "From one perspective, if the covering and refusal to offer data to the exchange cause the cucumber to be ended, the legitimacy of the agreements much of the time is debilitated, and the disappointed individual can cause his drowsiness and madness. Then again, visual deficiency and quiet are accidentally abused by numbness and inability in situations where there is a concealed blemish in the exchanged products, particularly without the getting party's trust and trust in the genuineness and trustworthiness of the other party. He's the whole of the two best advantages that might be the merchant's quietness about the gross deformity of Ted It isn't on the grounds that it is in the agreement of support of the convenience of each gathering and it can not be relied upon from anybody to give all data about the points of interest and burdens of the merchandise to the gathering, yet if the imperfection is covered up and can not be done with a customary examination. He understood that there is an ethical obligation to express that there is a shrouded imperfection. "(Katouzian, 1395, 5, 330) He further states:" Some of the time the refusal to pronounce a deformity is likewise in a situation which, in seeing the custom It is slyness and misdirection, and it gives the injured individual the directly to surrender. For instance, if the vehicle purchaser advises the merchant that he plans to go with a vehicle purchased for quite a while and request that he let him know whether there is an oversight in the tires, and the dealer won't instruct him to pitch the vehicle to him, This quietness is double dealing and abuse of the purchaser's trust. "(Katowice, 1395, 5, 332) Another legal advisor has called quietness" maligning "or" invalidation ", which makes it answerable (Ja'fari Langroudi, 1357, $1,781)$ Quietness in contracts when it covers reality and tricks the gatherings to the agreement, at that point the quiet of the state Mel, and falls inside the extent of

18 sciendo Journal of Legal Studies Volume 23 Issue 37/2019 ISSN 2457-9017; Online ISSN 2392-7054.

Web: publicatii.uvvg.ro/index.php/jls. Pages $16-32$ 
Mir Khalili, S.A., Kalantari, A., Rezaei Zarchi, F., (2019)

Criminal responsibility for concealing truth in finance

Article 438 of the Common Code (Ozia, 1371, 232). In this manner, as indicated by the previously mentioned issues, notwithstanding al-Tabas, the directly to any deficient structure and explanation can be viewed as one of the instances of camouflage of reality, and the quiet individual Capable.

\section{Concealing Truth in Contracts}

In the Imamiyah jurisprudence, the basis for the formation of a contract is the freedom of individuals and the provision of personal interests, and discussions have not been called the obligation to provide information, although, in some cases, goodwill in concluding a contract is fully emphasized with the full presentation of the facts and facts relating to that contract. Is:

1- Bidding: The Bidding Agreement is a bargaining contract with parties to negotiate and bargain to determine the price of goods. The seller tries to earn as much profit as possible, while the buyer tries to reduce the price of the product in any way possible. In this type of contract, the seller has no obligation to express the initial price of the goods to the buyer. (Mousavi Khomeini, 1390, 1, 502; Agent, $1417,3,218)$. This type of bet is superior to that. Because it only obeyed the general provisions of the contract, and there is no special clause that would oblige the vendor to comply with their obligations (Bagheri, 2005, 42)

2- Mourabah: In the moorabah Bay, the seller is obliged to honestly and with goodwill bring the details of the price to the buyer's knowledge and, once the price has been determined, the agreed profit must also be determined and the contract must be established and implemented. (Agent, 1417, 3, 428). The difference between this type of contract with the first type is that the initial price is clearly specified at the time of negotiating the contract. (Ibn Rushd, 1935, 2, 211)

Now, if the seller deceives the customer in the contract because of the fact that the contract is fraudulent, according to the opinion of the majority of the jurists, the client has the right to withdraw from the bond and cancel the transaction, or consent to this kind of transaction. (Amali, 1374, 3, 431; Mohaghegh Helli, 1415, 2; 37; Mousavi Khomeini, 1421, 1, 503). Although a group of jurists believes that, if satisfied, the buyer has the right to increase the amount of the seller, unlike the truth, to the top Get rid of it. (Najafi, 1404, 8, 438). Even when the seller buys several goods together and wants to sell them without providing details of the truth, the price can not distribute the total price to the various goods and inform the buyer only to the bank. (Mohaghegh Helli, 1415, 2, 37), but the price of each commodity should be expressed in a straightforward manner.

The reason for the moratorium contract is that the customer is solely dependent on the seller on the original price and believes in his statements, the maintenance of this contract is necessary for fraud and good faith. (Kashani, 1438, 5, 225)

Of course, with regard to the principle of non-profitability of a person who buys a 
Mir Khalili, S.A., Kalantari, A., Rezaei Zarchi, F., (2019)

Criminal responsibility for concealing truth in finance

financial asset to sell it, it is not necessary to indicate the purchase price, but in cases where according to the Shari'a and the law the buyer must inform the buyer about the purchase price, costs and profit, The seller must state the truth in the truth.

3. Bidding: To the resale contract for the same amount as the seller has purchased, in other words, the sale has been defined without profit.

4. Selling money: The seller, after expressing the truth about the purchase price, sells the property at a price below the initial price.

Of course, some jurists have introduced a different type of deal that the seller must declare the truth of the price, which is called a bargain in which the seller sells a share of his own property at its initial price, and the buyer pays the price of the whole price. Becomes a contract partner. (Ameli, 1374, 3, 437). In these contracts, it is necessary to disclose the initial price, since it is generally known to the buyer that he intends to sell the ruble to one of the types of contracts, which may cause the customer to close the contract $\mathrm{He}$ is encouraged because, as a rule, the client thinks that the type of contract is safe from dealer fraud and this shows that the buyer trusts the information and statements made by the seller about the goods and, due to this trust, Jurisprudence and law, the dealer is responsible for the disclosure of the truth.

\section{Conceal the truth in contract related goods}

In cases where the contract is related to the goods, the expression of facts and facts about the goods and services that have a particular effect on the health of individuals is very important. Responsibility for people who are illegitimate to use the trust of shopkeepers and give them defective and hazardous goods instead of safe and safe products and not tell them the truth are important legal issues.

The jurists do not substitute the product for declaring the perfection that does not exist or hide the attribute that causes the defect of the goods. (Najafi, 1404, 23, 317). Subversion of goods is a kind of darkness that darkens the supplier of the subject of the transaction in order to make non-right possible (Ameli, 1995, 1, 329) In Iranian law, the legislator has stated in several laws the problem of misconduct: Article 438 of the Civil Code states in the definition of misconduct: "An operation that deceives a party to a transaction." One lawyer states that he has a loyal commitment to guaranteeing the safety of the goods. "The seller is not only responsible for providing the customer with valuable information, but also must provide him with information about how to use it and to escape potential risks, This obligation is of a contractual nature because in each seller the seller is implicitly obliged to give all the necessary information on the use of the vendor and its hidden and obvious defects to the buyer and to prevent him from potential losses arising from the goods sold, He does not fulfill his obligation, and as a

20 sciendo Journal of Legal Studies Volume 23 Issue 37/2019 ISSN 2457-9017; Online ISSN 2392-7054.

Web: publicatii.uvvg.ro/index.php/jls. Pages $16-32$ 
Mir Khalili, S.A., Kalantari, A., Rezaei Zarchi, F., (2019)

Criminal responsibility for concealing truth in finance

result, he will be liable for any compensation The Last "(Katouzian, 2008, 115)

The terms of the contract are either explicitly stated in the contract or implied by the nature of the contract, customs and habit. A commitment to provide the information required for the use of the goods from the supplier to the customer as an implicit condition in the contract is acceptable, and the supplier of the goods is obliged to provide the customer with the potential losses in relation to the method of exploitation of the goods and the risks contained therein. (Kashani, 1360, 99)

Misbehavior in a variety of cases, such as corrupt supplies, sexually transmitted sexual acts, sexually transmitted pornography that date out, the supply of fraudulently made goods, supply of goods in violation of the standard, the supply of goods in which foreign materials are mixed with the original material, Supply of hazardous goods, supply of defective goods, low-cost goods and so on. In all of these cases, there is a case of fraud, and the concealment of truth has been created in practice.

\section{Evidence of the truth in contracts}

The proof of the truth in the contracts is signs.

Observing ethical principles and values and adhering to things such as honesty and justice, fairness, faith in the covenant, full statement of the facts, and the absence of any deception in the realm of contracts is one of the imperatives and requirements of the Islamic religion, as emphasized in the Quranic verses.

"(A)" or, that is, the provisions of the law of the law of the time of the adoption of the provisions of the Law on the Protection of the Rights of All Persons "(Nisa: 29) O Believers! Do not eat the property of one another in vain or in an illegitimate manner unless it is a business that is carried out with your consent."

This verse actually forms the basis of Islamic law in the issues of "transactions and financial transactions," and for this reason, the jurisprudents of Islam argue in all cases of transactions, the verse addressed to the believers and states that "Do not eat property of each other in the wrong way or in the wrong way", that is, any property seized in another property which has been forbidden without the right and without a rational and logical authorization, and has been made known to all as "false", which has a broad concept. Unless you seize the property of others through trading that stems from the existential satisfaction of both parties, according to this, all exchanges of financial and nouveau (Makarem Shirazi, 1374, 3, 357).

The purpose of falsehood is that which is lost and some say that falsehood is something that is contrary to reality and truth.

It is used in this verse that sin is more sinful when it comes to knowledge and knowledge of it or if it is possible for science to know (Tabretsi, 1372, 1, 144).

As in the hadith of Prophet Sunnī, the Prophet (pbuh), the Prophet (pbuh) said that "Alrzq is the component of the transcendence of mana al-fatima"; the day is the 
Mir Khalili, S.A., Kalantari, A., Rezaei Zarchi, F., (2019)

Criminal responsibility for concealing truth in finance

people of the Quran, it is not an oath of trade, the appearance of the verse implies the authenticity of the seizure of the property, And the full agreement of the parties is formed (Sharif Lahiji, 1373, 1, 465).

With the precision of the meaning of the verse, it can be seen that the signification of "non-trading" is the existence of satisfaction and includes honesty and respect for integrity (Tabatabai, 1417, 1, 418).

Undoubtedly, a person who does not have honesty and deceit in contracts and transactions will cause dissatisfaction with one of the parties to the contract and will result in the claim being canceled. In other words, the lack of truth and eating the property of others without the consent of truth and honesty in the contract contradicts.

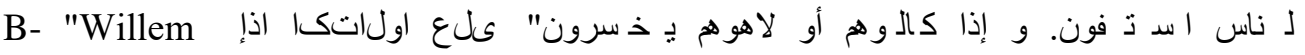
(Mutaffyn: 1-3)

Wave on the coworkers. Those who take on the people from all walks of life will end up. And when they give them a modem or weight, they reduce it.

In the Holy Qur'an, the emphasis is repeatedly on the issue of combating subversion and frauds in weight and in moderation, these verses refer to the observance of justice in Kiel and weighs it as a part of the principle of justice and order that governs the whole universe.

Basically, justice and justice, order and accounting are, in everywhere and everywhere, a fundamental principle, and any deviation from this principle is dangerous, especially the lack of capital, eliminates the trust and confidence that is the key to exchanges, and the system Economics is divided (Makarem Shirazi, 1995, 12, 113).

Some commentators include the problem of the sale of goods, including the lack of sales in transactions and the reduction of materials or the quality of goods in the production of goods and concealment of the truth to them, and, of course, the broader concept has generalized to any kind of misconduct in the performance of duties. Makarem Shirazi, 1374, 12, 113).

Counterfeiters betray others, and when they sell something to others by modem or weight, they reduce and deduct. However, in these verses, it is a word of weight and weight. But the shortage is not attributed to weight and kiln - because at the time of descent these verses were weighed down by the weighing and kale, so it is referred to them - but the verses of the verses are the reverence of low income and supply misery in various ways (Najafi Khomeini, 1398, 18, 202). Therefore, in these verses, abolition must be made and extended to other cases of misrepresentation.

22 Sciendo Journal of Legal Studies Volume 23 Issue 37/2019 ISSN 2457-9017; Online ISSN 2392-7054.

Web: publicatii.uvvg.ro/index.php/jls. Pages $16-32$ 


\section{Traditions}

The narrative: "And the Prophet (peace be upon him), and the Prophet (peace be upon him), (Saduq, 1413, 3, 195) is a criminal who is a criminal who is in the place of Hell but a businessman who is entitled to Take the right.

The criterion of doing business in Islam is not better than making money, nor is it a way of learning wealth, but it is justice and fairness, the businessman must avoid the lies and clumsiness of the truth. According to this narrative, the parties to the contract should beware of oppression, concealment, and the violation of each other's rights.

B-Narrator: مدق ع لوقيف مذذب اوعمس و مهبولقب مبلإ اوعرأ و مهبديأب ام اولققأ Extruded and soldered in the form of screeds and screeds, and also in the form of scaffolds and tiles, and also in the form of scourers and extruders, as well as in the form of scouring and polishing, and the use of alcopops and alcohols and alcohols, and in the manufacture of lacquer and lacquers, and in conjunction with the corruptions of the corruptors. "(Kellini, 1407, 5, 51)

Imam Baqir (AS) said, "Imam Ali (AS) went out of Kufa Darulamaret at dawn, while he was lying on a canal, circled in the markets of Kufa and stood in front of the merchants of each market and shouted," O business people of God. "The bazaaris, when they heard their cry, conveyed what they were holding and listened to all his words, saying," Call on God for nothing more than anything else, bless you with blessing, take the honey shoppers and get close to them. "Stay away from oath, lie and oppression, treat the oppressed fairly, do not go away, step down and balance Complete the value of goods and people, not least in the field of corruption. In this narrative, promoting goodwill and trusting each other in buying and selling is recommended, therefore, the seller must comply with the facts regarding the quantity and quality of fairness and justice.

The Prophet (pbuh) said to Zaynab that he was selling perfume: "Lazinb al-Atar'ah al-Hula'a izā-a'yat al-Fawah and 'The cleaner person is more precarious and it's not for us who betrays Muslims. It is clear from this narration that respect for honesty and the avoidance of deceit at the beginning of Islam has been emphasized.

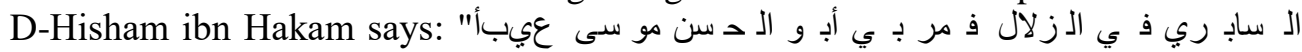

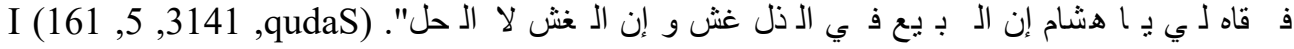
was selling Shapouri's shawls in the shadows that Imam Musa bin Ja'far (AS), while riding, walked away from me, and said to me: "Hisham is a shamrocker in the shadows, and it's not lawful." With the precision of the concept of faint, it can be understood that the concept of the faintness of the concealed truth or the purpose of which is to conceal reality is the opposite. (Mamaghani, 1381, 1, 191). By following these traditions, it can be seen that contracts must be made with truth and justice and fairness, and the responsible person is responsible. 


\section{The principle of health}

Health in the word means being free of pests, imperfections and defects. (Amid, $1360,2,1220)$. The health of the goods is a part of the contract while entering into a contract, in the contract of sale, the contract requires that the goods be healthy and without defect. (Mohaghegh Helli, 1415, 2, 290). So, in every contract on the basis of The health of the subject is shaped, according to the principle of health, the supplier must deliver the healthy goods, and this principle is considered as the implicit condition of the contract accepted by the jurists. (Najafi, 1404, 23, 33)

Muslims in their deals carry goods that are traded on health and free of defects. In this theme, it can be said that this principle is in accordance with the religion of Muslims, in a narration from Imam Sadiq (AS) regarding oil that is defective: If the intention You can inform the buyer about the sale of the oil. (Al-Amali, 1409, 12, 66)

According to the contents of this narrative, it can be said that in each transaction the principle is on the health of the goods, and when the seller refuses to express the truth about the defect of the goods, he has committed the act and is responsible.

\section{The principle of reality}

According to this principle, the supplier is obliged to state the qualities and facts of the goods, and if the product has the characteristics that it is in the making of the decision to conclude the contract, the supplier must be required to state the reality of the goods. The statements and narrations stated support this principle. The rights of the caretakers due to the idea, the violation of the description, the defect, etc. are used in confirmation of this principle. (Alizadeh, 1382, 109) Thus, concealing the reality and concealing the defects of the goods can lead to concealment of responsibility.

Criminal Liability Concealment in Contracts

One of the major crises in human societies is economic dilemmas. Subversion of goods is among these problems, which, in addition to creating insecurity in domestic markets, affects international trade and inflicts considerable harm to the interests of consumers. The growth of technology and the emergence of new inventions based on sophisticated techniques produce a variety of goods and products. Unidentified products have been brought to the community. The complexity of these goods is that it is not possible to detect the health or disadvantage of the goods by ordinary people, and even in some cases the consumer does not correctly understand the method of using that product and because of the lack of knowledge of the fault of the goods or even in cases of lack of health of the goods due to lack of awareness Through its use, it has been

24 sciendo Journal of Legal Studies Volume 23 Issue 37/2019 ISSN 2457-9017; Online ISSN 2392-7054.

Web: publicatii.uvvg.ro/index.php/jls. Pages $16-32$ 
Mir Khalili, S.A., Kalantari, A., Rezaei Zarchi, F., (2019)

Criminal responsibility for concealing truth in finance

damaged and harmed; therefore, lawyers are required to provide consumers with information and methods for the correct use of the goods in order to protect the consumer, producers and sellers. Therefore, in commodity supply contracts, the complexity of the goods and services provided and the impact of these goods on the health of individuals leads to the loss of their previous remedies and the need for strengthening of criminal law. Therefore, the elements of misconduct crime include:

\section{Legal element}

In the Islamic Penal Code, there is no article about the deception in the contracts by concealing the truth of the matter. However, the law stipulates the perpetrators of bribery and embezzlement and fraud in article 1 of the definition of fraud and the punishment of the crooks: "Everyone by way of tricking people into the existence of corporations or factories, or fictitious institutions or possession of the deceitful possessions and powers Or hopes for unrealistic affairs, or frightens of unrealistic events or incidents, or chooses the name and the title of a vendor, and acquires funds or funds for one of the aforementioned means or other means of counterfeiting, or funds or documents, or remittances, or bills or accounts, etc., and This way is to take away another's property as a fraudster and additionally The rejection of the property of the owner is condemned to imprisonment from one to seven years and the equivalent of the financial penalty received ... "In the article, it is possible to pay attention to two parts and to recognize Madras as a fraudstor and to be tried. First, the legislator says, "To hope for things that are not real ..." Let's assume that a car that has previously been crashed and repaired will be sold to someone else instead of the car without hitting someone else. However, the seller hopes that the buyer will buy a healthy product that is unrealistic, and thus his willingness to buy goods at a price more than real price. Secondly, in the other part it says: "To one of these devices or other counterfeit goods ..." Here again, it is possible to count the operations that are carried out to conceal the truth from the customer's point of view in a fraudulent manner, and thus the deceiving person can be regarded as The fraudster has been tried and punished, but since he must commit a criminal act in a fraudulent manner, the fraud can not be considered to conceal the truth (Mir Mohammad Sadeghi, 1394, 60).

\section{Material element}

\section{A) The Deed is committed}

The demonstration of submitting unfortunate behavior must be deceitful, misrepresentation can be false announcements or the supply of perilous products, previous history, degenerate, etc, and quiet involves conning in situations where the declaration of reality of a viable basic leadership choice is extortion. Along 
Mir Khalili, S.A., Kalantari, A., Rezaei Zarchi, F., (2019)

Criminal responsibility for concealing truth in finance

these lines, if there is something in the stock, for example, deficient, degenerate, or perilous, it is mandatory to express it, and afterward his activity will be a sort of control. (Najafi, 1404, 23, 246). The provider will be viable in submitting extortion so as to change the subject of the agreement so that the watcher views it as a decent and great item, while the fact of the matter is extraordinary, or the inconvenience of the merchandise is to stow away and endeavor Make it in the same class as it is by all accounts. (Address, 1329, 4, 438)

By and large, straightforward and quiet disguise won't prompt legitimate misrepresentation, however in situations where the declaration of actualities is essential, it hides the camouflage of realities. (Mousavi, 2007, p. 244) There is no particular managing in Iranian law in regards to quietness, yet it proceeds to The death of the real enthusiasm of legal counselors is that quiet and evading reality about the merchandise are wrong and thought about a deceitful demonstration.

B) The conditions for the fumble of merchandise

The wrongdoing of merchandise is because of the satisfaction of the accompanying conditions:

1-The presence of knows the decrease of the estimation of the merchandise so that everything that lessens the estimation of the merchandise is checked. (Allamah Heli, 1422, 2, 170) Some different jurisprudents Deformities are considered as a moderate dimension among wellbeing and flawlessness, with the view that gentle wellbeing is the phase among defect and flawlessness. (Ansari, 1411, 2, 265)

In common law, he has been quiet about characterizing the deformity, yet he thinks about the model of acknowledgment as the rate of productivity of merchandise, as stipulated in Article 479 of the Common Code in the rent talk: "The imperfection that causes the end of a rent is a deformity that outcomes in lost benefit revenue driven." It is standard to do as such, yet in the purchaser security law of Article 4, Article 1 expresses: "The motivation behind the imperfection in this law is unnecessary, hindrance or change in a circumstance that prompts a decrease in the estimation of products or administrations."

As per Article 423 of the Common Code, the deformity of the products gives the client the directly to end the agreement, which is mystery and accessible at the season of the agreement, and as per Article 424, "the imperfection is esteemed to be a mystery that the client has not had at the season of the world, that the absence of information emerging from It's that the blemish has truly been, or it has showed up, yet the client has not been inspired. " In this way, the directly to end is because of the obliviousness or absence of consideration of the client to the imperfection, which is conceivable that the deformity is evident yet the purchaser has not focused. Be that as it may, the distinction between the case and the cucumber is the certification of its usage, notwithstanding the cucumber, it is the directly of the client to acquire the request.

26 S sciendo Journal of Legal Studies Volume 23 Issue 37/2019 ISSN 2457-9017; Online ISSN 2392-7054.

Web: publicatii.uvvg.ro/index.php/jls. Pages $16-32$ 
The blemish in criminal law varies from the deformity of the merchandise in private law, and what is considered in the correctional code of imperfection may not be viewed as an imperfection in private law, criminal offense can be completed in two different ways. An) Unacceptable supply: when the ware is imperfect, for example, the blending of merchandise with different products, the defilement of the merchandise, the danger of supply of products for non-quality merchandise and the supply of merchandise, the supply of which has lapsed, the supply of products in which the materials Unapproved additional items have been utilized, the supply of merchandise from fake products, specifically, in nourishment, drinking and pharmaceutical items. (B) Accommodation of a structure: when the products are not flawed and there is no deformity in it, and it might be viewed as of a prevalent individual, yet it is by one way or another disallowed, the law denies this kind of supply, minimal effort, costly, non-recognition of guidelines, change of history The utilization of merchandise, the buy and closeout of unlicensed merchandise, particularly the medication, the clearance of non-paid medications, and the absence of announcement of the estimation of merchandise to the client are instances of maladaptive structures. (Ghanavati, 2006, p. 173). In this way, in the criminal wrongdoing, the utilization of the word misrepresentation is more fitting than the word imperfection, since extortion includes the two sorts of unfortunate behavior.

2-The presence of double dealing: the trickery component in the agreement is the nearness of a breaking down component in the agreement, with the goal that the demonstration beguiles the other party and is compelling in choosing to close an agreement; trickiness must have an inborn impact and affect the exchange; That the buyer has been betrayed and has stopped to finish up an agreement which, in his view, has different conditions. (Khoi, 1417, 5, 386) So the season of double dealing must be made before the exchange and the motivator is concurred and urged by him to close an agreement.

C) Realization of losses

In jurisprudence, there are two views regarding the condition of harm. A group of jurisprudents is of the opinion that there should be a component of harm in the supply of goods and that the evidence provided by the reasoning is attributed to the cases in which the losses have been incurred. (Ansari, 1411, 2, 247) According to The opinion of this category should give the supplier the responsibility to ensure that the supply of the goods would make the buyer's losses material. (Musavi Khomeini, 1421, 337; Khoyi, 1417, 4, 283) Another group of jurists believes that the supply of goods is liable, although it does not lead to a loss. It can be said that the purpose of harm is from the perspective of this group of personal losses that this kind of harm is not necessary for the realization of the crime, but the criterion of realizing the crime is the harm to society that exists in the supply of goods. 
In criminal law, many cases relate to the realization of harm, the interests of the individual and society, and so on. Financial crimes are basically a crime combined with losses and profits, causing losses to the other party, such as theft, betrayal, and fraud. Losses are an essential element of the material element of these crimes. (Mir Mohammad Sadeghi, 1374, 197). Given that maladaption is a crime against property, there must be a harm element in order to be responsible for it, but in many cases maladaptation, in particular, the form of that element of harm to existence. Unless we consider the harm to the community and give it a criminal liability.

\section{Relationship of causality}

In the Jurisprudence there are two types of causal relationship in commodity misconduct. A) The relationship between the causal relationship between the supplier's verb and the losses to the deceived person. B) The relationship between the causality between the act of fraud and the deceived person's action.

Some jurists consider both types of relationship necessary to realize the misconduct of existence, and the other just considers the second relation, the causal relation between the act of fraud and the deceived person's action. (Ansari, 1411, 2, 146; Mousavi Khomeini, 1421, 336). Of course, there is no consensus in determining the examples of this relationship, according to a view that only satisfies the second relation, due to the existence of the relation between the act of fraud and the entry of harm It has been argued that the losses incurred are not due to fraudulent acts, but to the detriment of the effect of the deceived person's actions, and there is a fraudulent act and a loss of mediation called a deceived person's action, so that there can not be a judgment of existence The relationship is causal, a fraudulent act only serves as the initiator of the introduction and the field of entry of the damage to the supply. Therefore, in order to realize the misconduct, only the relationship between the fraudulent act and the deceitful action is sufficient. (Mir Mossadeghi; Daneshvar Saberi, 2002, 81). If we look at the constitution from the criminal point of view, mere fraudulent operations are intended to deceive the other party, based on trust and honesty. The intention is to conclude a contract, subject to punishment and an eagle, but in private law, the purpose of which is more to compensate for the deceitful losses and the strength and necessity of contracts, it can only be used for such acts of conduct that would deceive the party being contracted. (Katowice, $1395,5,343)$. Therefore, the causal relation between fraudulent operations and deception must be established.

28 Sciendo Journal of Legal Studies Volume 23 Issue 37/2019 ISSN 2457-9017; Online ISSN 2392-7054.

Web: publicatii.uvvg.ro/index.php/jls. Pages $16-32$ 
Mir Khalili, S.A., Kalantari, A., Rezaei Zarchi, F., (2019)

Criminal responsibility for concealing truth in finance

\section{Spiritual element}

To enforce the offense, the violation of the rules and laws of the legislator alone is not enough. The verb or the abandonment of the criminal act must be the result of the will and will of the subject. In other words, there must be a relation between the material verb and the mental states of the subject in order to convict the perpetrator. The attention of the subject to the outcome of the criminal act is deliberate, but according to the amount of attention given by the subject to obtaining the result, the subject's subjugation results in different results. (Ardebili, $1383,1,348)$. The spiritual element of science and consciousness commits the defect of the goods and the fraudulentness of the verb or the abandonment of the verb that is intentional, in addition to the two, the science and the intentional, which is called general subjectivity, must be the criminal intention Specific misconduct is interpreted.

\section{A general abuse}

The science and consciousness of committing commodity defects causes him to fail to declare it. One of the general conditions of science is that without which the person is not responsible. In jurisprudence regarding the sale and sale of defective goods, because it considers most of the legal works and consideration of the buyer's compensation, he does not consider the seller's knowledge and knowledge to be valid for these works. (Akhund Khorasani, 1406, 81; Esfahani, 1418, 100) and in each case the seller is obliged to compensate the seller, whether he is aware or not aware. Of course, in relation to criminal responsibility, according to some jurisprudents, for the truth of the deception title, we must commit ourselves to the disadvantage of the commodity, so that we can expose the effects of the criminal misconduct on him. (Mousavi Khomeini, 1421, 366) In addition to the knowledge and consciousness of the perpetrator, he must deliberately and with the discretion of selling the defective product to another, and if he commits reluctance and compulsion to do so, he is exempted from criminal liability.

\section{B-Special insubordination}

It is not enough to have general malpractice alone; in the particular misconduct, the perpetrator must have the intention of having the result of a criminal act, which is the supply of a defective and illegal product. (Ardebili, 1383, 1, 350) Therefore, there must be a result in the crime of misconduct of goods.

\section{Conclusions}

In financial related issues in ware supply gets, the unpredictability of the products and enterprises gave, and the effect of these merchandise on the soundness of people, make it outlandish for private-law instruments to be adequate. In this 
Mir Khalili, S.A., Kalantari, A., Rezaei Zarchi, F., (2019)

Criminal responsibility for concealing truth in finance

article, by looking into the stanzas and portrayals, the rule of wellbeing, and the introduction of the truth of the merchandise and its application to the components of the wrongdoing, I infer that the covering of reality in the agreements identified with the products on the off chance that it makes hurt the individual or society, notwithstanding respectful obligation, likewise prompts criminal risk To be arraigned and indicted and to keep the event of financial interruptions.

\section{Acknowledgements}

The authors thank the anonymous reviewers and editor for their valuable contribution.

\section{Funding}

This research received no specific grant from any funding agency in the public, commercial, or not - for - profit sectors.

\section{Author Contributions}

The authors conceived the study, carried out the literature review agenda and was responsible for the design, data collection, legislative analysis and case interpretation.

\section{Disclosure Statement}

The authors have not any competing financial, professional, or personal interests from other parties.

\section{References}

1. Akhund Khorasani, Kazem, (1406), Margin of the Compass, First Edition, Ministry of Islamic Guidance, Tehran

2. Ardebili, Mohammad Ali, (2004), Public Penal Law, Fifth Edition, Publishing, Tehran.

3. Esfahani, Mohammad Hussein, (1418), the margin of Makbas, the first edition, Dar al-Mustafa (PBUH), Salaha al-Tatar.

4. Ansari, Morteza, (1411), Al-Mekhasb, editors Mohammad Javad Rahmati and Seyyed Ahmad Hosseini, first edition, Eldar Al-Taskhair's letters, Qom.

5. Ozia, Parviz (1992), A Comparative Study in the Laws of France, Britain, Islam and Iran, Third Edition, The Book of Transformations of Private Law, Tehran University Press, Tehran.

6. Barykloo, Alireza (2008), Civil liability, second edition, Tehran, publication of Tehran.

7. Bagheri, Ahmad, (2005), Civic Fiqh (Taleqi). First Printing, Tehran, Tehran.

30 sciendo Journal of Legal Studies Volume 23 Issue 37/2019

ISSN 2457-9017; Online ISSN 2392-7054.

Web: publicatii.uvvg.ro/index.php/jls. Pages $16-32$ 
Mir Khalili, S.A., Kalantari, A., Rezaei Zarchi, F., (2019)

Criminal responsibility for concealing truth in finance

8. Jafari Langroudi, Mohammad Ja'far (1357), Encyclopedia of Law, first edition, publication of the Rashad Foundation.

9. Haramali, Muhammad b. Hassan (1409), Wasejal al-Shi'a, first edition, Al-Al-

Bait Institute, Qom.

10. Khattab, Mohammad bin Muhammad, (1329), Muhayb al-Jalil, Sharif Khalil, Al-Sa'ada, Cairo.

11. Khoyi, Seyyed Abu al-Qasim, (1417), Mesbah Al-Safashahi fi ammunalat, first print, Qom.

12. Sharif Lahiji, Mohammad bin Ali (1373), Lahiji's commentary, published the first publication.

13. Sadouq, Muhammad ibn Ali ibn Babuyeh (1413), I La Yahzareh al-Fakheh, Second Edition, Islamic Publishers Office affiliated with the Qom Seminary Teachers Society, Qom.

14. Tabatabai, Mohammad Hussein (1417) Al-Mizan Fi Tafsir Al-Quran, Islamic Publications Office of the Community of Teachers in the Seminary, Qom.

15. Tabarsei, Fazl ibn Hassan (1372), Assembly of the Faith of Al-Quran, Naser Khosrow Publishing House, Tehran.

16. Ameli, Zayn al-Din al-Bin Ali (1374), Al-Razda Al-Behayee, Ph.D., Ismaili Printing, Qom.

17. Amali, Mohammad bin Maki (1417, Al-Duras al-Sharaei Fiqqul al-Amamiyah, Second Edition, Office of Publications Affiliated to the Teachers Society, Qom.

18. Allameh Helli, Hassan ibn Yusuf (1422), Tahirir al-Ahqam Al-Sharaieh Ali Religion Al-Amamiyah, First Printing, Imam Sadiq Institute, Qom.

19. Alizadeh, Mehdi (2003), Subversion of Goods, First Edition, Razavi University of Science and Technology, Mashhad, Iran.

20. Amid, Hasan, (1360), Farsi Farsi Amid, Third Edition, Amir Kabir Publishing.

21. Ghanavati, Jalil; Javar, Hossein (2006) "Comparative study of prosecuted maladjustment in British and Iranian law and Imamie jurisprudence", Volume 10, Issue 3, 160-180

22. Katouzian, Naser (1395), General Terms of Contract, Liquidation of Contract, Tenth Edition, Public Joint Stock Company, Tehran.

23. Kashani, Alaeddin Abu Bakan Massoud, (1438), Al-Sana'ah's Faith in the Order of Al-Shariah, First Printing, Karachi.

24. Kashani, Mahmoud, (1360) Non-contractual obligations and contracts, Official Gazette Publications

25. Kelini, Mohammad bin Yaghoub (1407), Al-Fifi, Moderator: Ali Akbar Ghaffari, Fourth Edition, Darek-e-Elelaslami, Tehran.

26. Mamqani, Abdullah (2002), Nahiyat al-Maqal fi ta'mulayya al-Mu'al al-Imal, Samen al-Hajj, Qom. 
Mir Khalili, S.A., Kalantari, A., Rezaei Zarchi, F., (2019)

Criminal responsibility for concealing truth in finance

27. Mohaghegh Heli, Najmd al-Din (1415), Shira's al-Islam al-Fayes al-Hilal and al-Haram, first edition, Encyclopedia of Islam.

28. Makarem Shirazi, Naser (1374), Sample Interpretation, First Printing, Dare Elektb al-Eslamiyeh, Tehran.

29. Moosavi Khomeini, Seyyed Ruhollah (2011), Tahrir al-Waslah, Second Edition, Dar Al-Alam Publications, Qom.

30. Musavi Khomeini, Seyyed Ruhollah (1421), Al-Baba's Book, The First Book of Imam Khomeini, Tehran.

31. Mir Mohammad Sadeghi, Hossein (1995), Analysis of Criminal Law Principles, Second Edition, Shahid Beheshti University Jihad Publishing Center, Tehran.

32. Mir Mohammad Sadeghi, Hussein (1394), Special Criminal Law 2 Crimes Against Property and Property, Forty Wives, Legal Foundation, Tehran.

33. Mir Mohammad Sadeghi, Hossein, Daneshvar Sani, Reza, (2012), The Rights of Subsoil Supply in Imamieh Islamic Jurisprudence, Law of Iran and Kamenla, Legal Investigations, No.57,51-95. 